ECONOMIC GROWTH CENTER

YALE UNIVERSITY

P.O. Box 208629

New Haven, CT 06520-8269

http://www.econ.yale.edu/ egcenter/

CENTER DISCUSSION PAPER NO. 940

\title{
Group versus Individual Liability: A Field Experiment from the Philippines
}

\author{
Xavier Giné \\ World Bank \\ Dean Karlan \\ Yale University \\ Innovations for Poverty Action
}

July 2006

Notes: Center Discussion Papers are preliminary materials circulated to stimulate discussions and critical comments.

Contact information: xgine@worldbank.org,dean.karlan@yale.edu. We are grateful to the World Bank Research Committee and the National Science Foundation CAREER SES-0547898 for funding this research. We thank Tessa Bold, Jim Engle-Warwick, Karla Hoff, Jonathan Morduch, Mark Schreiner, Chris Udry, Bruce Wydick and seminar and conference participants at Berkeley, Chicago-GSB, George Washington, ParisJourdan, Santa Cruz, Stanford, Toulouse, Tufts, University of Washington, Yale and the World Bank for comments. We also thank Tomoko Harigaya and Melissa Scudo for superb research assistance. We thank Omar Andaya, Gerald Andaya, Zaldy Mantilla, Monette Perez, and the field staff of Green Bank for implementing the experimental protocols.

This paper can be downloaded without charge from the Social Science Research Network electronic library at: http://ssrn.com/abstract=917148

An index to papers in the Economic Growth Center Discussion Paper Series is located at: http://www.econ.yale.edu/ egcenter/research.htm 


\title{
Group versus Individual Liability: A Field Experiment in the Philippines
}

\author{
Xavier Giné and Dean Karlan
}

\begin{abstract}
Group liability is often portrayed as the key innovation that led to the explosion of the microcredit movement, which started with the Grameen Bank in the 1970s and continues on today with hundreds of institutions around the world. Group lending claims to improve repayment rates and lower transaction costs when lending to the poor by providing incentives for peers to screen, monitor and enforce each other's loans. However, some argue that group liability creates excessive pressure and discourages good clients from borrowing, jeopardizing both growth and sustainability. Therefore, it remains unclear whether group liability improves the lender's overall profitability and the poor's access to financial markets. We worked with a bank in the Philippines to conduct a field experiment to examine these issues. We randomly assigned half of the 169 pre-existing group liability “centers” of approximately twenty women to individual-liability centers (treatment) and kept the other half as-is with group liability (control). We find that the conversion to individual liability does not affect the repayment rate, and leads to higher growth in center size by attracting new clients.
\end{abstract}

JEL Codes: C93, D71, D82, D91, G21, O12, O16, O17

Keywords: microfinance, group liability, joint liability, social capital, micro-enterprises, informal economies. 


\section{Introduction}

Microfinance is seen by many as a promising and cost-effective tool in the fight against global poverty (Morduch 1999; Armendariz de Aghion and Morduch 2005; Microcredit Summit Campaign 2005). Group liability, a contract feature found in many programs, is a common component in many microfinance programs. Many believe that this feature, because of its purported ability to overcome adverse selection and moral hazard problems, is a key innovation responsible for the rapid growth of the microcredit movement in credit markets for the poor. Its popularity can be linked to numerous perceived advantages. By making a group of clients liable for each other's loans, the lender can exploit local information to improve the screening, monitoring and enforcement. Under group liability, clients have an incentive to screen other clients so that only trustworthy individuals are allowed into the program. In addition, clients will make sure that funds are invested in profitable enterprises. Finally, enforcement is enhanced because clients face peer pressure, not just legal pressure, to repay their loans. Thus, by effectively shifting the responsibility of certain tasks from the lender to the clients, group liability claims to overcome information asymmetries typically found in credit markets, especially for households without collateral.

In recent years, however, some micro-lenders, such as the Association for Social Advancement (ASA) in Bangladesh or the Bank Rakyat Indonesia (BRI), have expanded rapidly using individual liability loans. Others, like BancoSol in Bolivia, have converted a large share of its group lending portfolio into individual liability lending. Even the Grameen Bank in Bangladesh, the precursor of group liability lending, has recently relaxed the group liability clause in the Grameen II program by allowing defaulters to renegotiate their loans without invoking group pressure. 
This shift from group liability to individual liability loans has accelerated as the microfinance community learns about some of the pitfalls of group liability lending programs. First, clients dislike the tension caused by group liability. Excessive tension among members is not only responsible for voluntary dropouts but worse still, can also harm social capital among members, which is particularly important for the existence of safety nets. Second, bad clients can "free ride" off of good clients causing default rates to rise. In other words, a client does not repay the loan because she believes that another client will pay it for her, and the bank is near indifferent because it still gets its money back. Third, group liability is more costly for clients that are good risks because they are often required to repay the loans of their peers. This may lead to higher dropout and more difficulty in attracting new clients. Finally, as groups mature, clients typically diverge in their demand for credit. Heterogeneity in loan sizes can result in tension within the group as clients with smaller loans are reluctant to serve as a guarantor for those with larger loans. In sum, while repayment may improve under group liability, the client base may be smaller, so it remains unclear whether group liability improves the lender's overall profitability and the poor's access to financial markets.

Despite being a question of first-order importance, empirical research on group versus individual liability lending has not provided policymakers and institutions the clean evidence needed to determine the relative merits of the two methodologies. ${ }^{1}$ The problem is that lenders typically chose the credit contract based on the context in which they operate. Since in practice most microlenders use one type of loan, it is hard to identify impacts from a cross-section of loan

\footnotetext{
${ }^{1}$ An empirical literature exists that examines within group lending programs, which group characteristics lead to higher repayment (e.g., higher social capital is the most common variable of interest), and this literature is often motivated by trying to test the same theories discussed here (Wydick 1999; Ahlin and Townsend 2005; Karlan 2005). See Ahlin and Townsend (2006) for an empirical analysis of the selection decision into group or individual liability.
} 
contracts if the different contexts have unobserved characteristics that influence its choice. Quoting Armendariz de Aghion and Morduch (2005),

"The best evidence would come from well-designed, deliberate experiments in which loan contracts are varied but everything else is kept the same."

This is precisely the goal of the paper. We use a randomized control trial conducted by the Green Bank of Caraga in the Philippines to evaluate the relative impact of group versus individual liability on client repayment and its overall profitability. Half of Green Bank's existing grouplending centers in Leyte, an island in central Philippines, were randomly converted to individual liability in three waves between August 2004 and May 2005. Using this conversion methodology, we are able to assess whether group liability overcomes information asymmetries and ultimately impact on access to credit.

The separation of adverse selection from moral hazard is one of the most difficult empirical challenges when studying information asymmetries in credit markets. ${ }^{2}$ In this paper, we isolate the effects from moral hazard by "surprising” existing group liability member, already peer-screened under group liability. We therefore address the question of whether the shift to individual liability exacerbates moral hazard by focusing on existing clients.

Whereas the literature has focused almost exclusively on the superiority of group liability in ensuring repayment, we find no change in repayment for those centers converted to individual liability, and higher growth both due to fewer dropouts and more new clients. In addition, we find that new entrants to the program had looser social ties to the prior members, suggesting that the screening imposed by group liability was limiting the growth of the existing programs. We find direct evidence that individual liability leads to less monitoring of each other's loan performance (although as noted, this lowered monitoring does not lead to higher default). Lastly, we find that

\footnotetext{
${ }^{2}$ See Karlan and Zinman (2006) for a similar separation of adverse selection from moral hazard in credit markets.
} 
those with weaker social networks prior to the conversion are more likely to experience default problems after conversion to individual liability, relative to those who remain under group liability. In sum, as conversions from group to individual liability become more commonplace, we take the first step towards understanding whether and how such conversions work.

The rest of the paper is organized as follows. Section II reviews the literature on group versus individual liability lending programs. Section III presents the experimental design and the administrative and survey data we collected. Section IV presents the empirical strategy and primary results on the impact of group versus individual lending on center and individual performance. Then, section $\mathrm{V}$ presents results from three surveys conducted one year after the initial conversion in order to learn more about the mechanism through which changes did or did not occur. Section VI concludes.

\section{Literature Review}

The theoretical literature has focused almost exclusively on comparing the repayment performance under group and individual liability. Ghatak and Guinnane (1999) suggest that group liability can help institutions improve repayment through four channels: (i) ascertaining how risky the borrower is (adverse selection), (ii) ensuring that the funds will be used properly (ex-ante moral hazard), (iii) ensuring that the borrower tells the truth in case of default about her ability to pay (monitoring), (iv) enforcing repayment if the borrower is reluctant to pay (voluntary default, or expost moral hazard). Group liability contracts in theory can lead to higher repayment because borrowers have better information about each other's types, can better monitor each other's investment, and may be able to impose powerful non-pecuniary social sanctions at low cost. 
However, there are other stories that suggest that group liability may instead jeopardize repayment. For example, Besley and Coate (1995) point out that borrowers who would repay under individual liability may not do so under group liability. This situation may arise if members realize that they cannot repay as a group. In this situation, since (if rules are adhered to) no further loans will be granted, members that could otherwise repay decide to default because the incentive of future credit is not longer present. This model also demonstrates that social collateral can help make joint liability work better than individual liability (baring the strategic default situation mentioned above). However, Sadoulet (1997) argues that "social collateral" induced by group liability is not sufficient to ensure high repayment rates. Finally, Rai and Sjostrom (2004) show that both individual and group liability alone can be dominated by a contract that elicits truthful revelation about the success of the peers' project. In their setup, high repayment is triggered by the ability of banks to impose non-pecuniary punishments to members according to their reports about their success and that of others. More importantly, if borrowers have the ability to write contracts with one another (i.e., side-contract), group liability contracts can be excessively burdensome.

This suggests that repayment is only one piece of the puzzle. The lender's ability to retain good borrowers and attract new ones is equally important to assess the overall profitability. Indeed, an institution with perfect repayment may be more profitable with lower repayment but a larger client base. Madajewicz (2003) argues for instance that under group liability, loan sizes are limited by what the group can jointly guarantee, so clients with growing businesses or those who get well ahead of their peers in scale may find that the group contract bogs everyone down. Below a certain scale, group liability dominates individual liability. But above a certain size of business, individual lending will be preferred by customers. One implication is that better-off clients tend to 
seek individual loans as they move forward and indeed, many institutions that offer group liability loans are now offering new individual-liability contracts for successful clients.

In the end, the relative contribution of group liability can only be determined empirically. Morduch (1999) and Armendariz and Morduch (2005) point out in their microfinance reviews that the performance of group liability contracts in developing countries has been very diverse. ${ }^{3}$ Thus far, however, since most claims are supported with anecdotes, we still lack good evidence on the relative importance of group liability vis a vis the other mechanisms, such as dynamic incentives, regular public repayments, etc. found in "group lending" schemes. Notice that throughout this paper we maintain an important distinction between "group liability" and "group lending." "Group liability" refers to the terms of the actual contract, whereby individuals are both borrowers and simultaneously guarantors of other clients' loans. "Group lending" merely means there is some group aspect to the process or program, perhaps only logistical, like the sharing of a common meeting time and place to make payments. The heart of this paper is testing whether a shift from group liability to "merely logistical" group lending leads to higher or lower repayment rates, client retention and to changes in group cohesion.

\section{III.Experimental Design and Data Collected}

\section{A. Experimental Design}

The Green Bank of Caraga, a rural bank operating in central Philippines, conducted a field experiment in which they removed the group liability component of their Grameen-style ${ }^{4}$ group

\footnotetext{
${ }^{3}$ See also Adams and Ladman (1979) and Desai (1983). On anecdotal evidence on the limits to joint liability, see Matin (1997), Woolcock (1999) Montgomery (1996) and Rahman (1999).

${ }^{4}$ This is a Grameen "style" program since the bank conducts some basic credit evaluation, and does not rely entirely on peer selection. The bank's evaluation steps include essentially two components: physically visiting the business or home to verify the presence of the enterprise and its size, and an assessment of the repayment capacity of borrowers based on the client-reported cash-flows of their enterprise.
} 
liability program, called BULAK ${ }^{5}$. Typically a center starts with 15-30 individuals residing in the same barangay (community). Centers grow in size as demand increases, without predetermined maximum sizes. Within each center, members divide into groups of five. Under the normal group liability system, those in the group of five are the first layer of liability for any default. Only if those five fail to pay the arrearage of an individual is the center as a whole responsible for an individual. ${ }^{6}$ New members joining an existing center are also assigned into groups after mutual agreement is reached. If at one point in time there are enough new members to form a new group of five, they may do so. Across the central Philippines, Green Bank has over 12,000 clients in over 400 BULAK centers in 27 branches. This study was conducted on the island of Leyte, and all 169 centers on the island were included in the sample frame.

All loans under the BULAK program are given to microentrepreneurial women for their business expansion. The initial loan is between $1,000-5,000$ pesos (roughly $\$ 18-\$ 90$ ). ${ }^{7}$ The maximum loan size increases by 5,000 pesos after every loan cycle, such that the maximum loan size in the $5^{\text {th }}$ cycle is 25,000 pesos. However, the loan size depends on repayment of their last loan, attendance at meetings, business growth, and contribution to their personal savings. The interest rate is 2.5 percent per month, calculated over the original balance of the loan. The client has between 8-25 weeks to repay the loan, but payments must be made on a weekly basis during the center meeting.

As part of the BULAK program, clients are also required to make mandatory savings deposits at each meeting. At loan disbursal, each member deposits 100 pesos plus two percent of

\footnotetext{
${ }^{5}$ Bulak means flower in Tagalog, but is also the acronym for Bangong Ug Lihok Alang sa Kalambuan, which means "Strive for Progress."

${ }^{6}$ Although many institutions that have this two-tier structure on paper do not enforce it in practice, Green Bank does enforce it. The payment of all members in a group is collected by the credit officer from group officials at the meetings. In addition, group members sign as co-makers for the rest of group members, thereby becoming the first to be liable if another group member is in default.

${ }^{7}$ Based on exchange rate of 56 Philippine Pesos $=1$ US Dollar.
} 
the loan amount into savings. In addition, each member must pay an additional ten percent of their weekly due amount (principal plus interest) into their individual savings account. Member savings may be used to repay debts and also act as collateral, although in this last case there are no fixed rules. Finally, 10 pesos $(\$ 0.18)$ per meeting are required for the group and center collective savings account. The center savings cover mostly the construction of the center meeting building (a small house or hut in the village) and other center activities, or as a last resort to repay member loans if the center is being dissolved and default remains. ${ }^{8}$ The group savings is held as collateral to cover arrearage within each group.

In the experiment, the Green Bank randomly converted existing centers with group liability loans to individual liability loans. All other aspects of the program remain the same (including attendance at center meetings and weekly payment made in groups). Hence, the only two features that changed are the group liability and the savings rules. By removing the group liability, no member is held liable for another member's default. Thus, members are no longer forced to contribute towards the repayment of other members in default and they are no longer required to sign as co-maker of loans for other group members. If Green Bank had enforced a stricter group liability rule, the change to individual liability would also have entailed the issuing of new loans when other clients were in default. In practice, however, loans were already being issued to clients in good standing even when other individuals were in default. For the conversion, the group and center savings were dissolved and shifted into individual savings accounts. The total required savings deposits remained the same. ${ }^{9}$ With the conversion of group and center savings into individual savings, there no longer were funds set aside to pay for center activities. Thus, all center activities in treatment groups must be paid for out of individual accounts on a per-activity basis.

\footnotetext{
${ }^{8}$ In our observation, this never occurred.

9 The new Personal Savings quota will be the previous amount of Personal Savings (based on the loan amount), plus P20, the amount previously given for Center and Group savings.
} 
Critical to the design is the fact that treatment centers were converted from existing centers, and not newly created. By comparing the repayment behavior of existing clients in group-liability centers and converted centers, we are able to isolate the impact of peer pressure imposed through group liability. ${ }^{10}$

Our sample includes 169 BULAK centers in Leyte, handled by 11 credit officers in 6 branches. Among these, 161 had been created before August 2004, when the experiment started. Green Bank's main competitors are NGOs (such as TSKI) which mostly offer group-liability loans and cooperatives (such as $\mathrm{OCCCI}$ ) which offer individual liability loans. At the time of the first conversion, about 28 percent of the existing centers were located in barangays with no other competitor, 53 percent of the centers were in barangays with at least one NGO and 47 percent of the barangays with Green Bank presence had at least one individual liability lender. ${ }^{11}$

In August 2004, we implemented the first wave of conversions in 11 randomly selected centers ( 1 center per field officer). In November, we randomly selected 24 more centers to be converted to individual-liability. In the sample frame for this randomization, we included 8 additional centers formed after August 2004. Finally in May of 2005, we randomly selected 45 more centers from the 125 remaining. As of January 2006, the date of the data with which we conduct the impact analysis, there are 78 converted centers and 86 original (group-liability) centers ( 2 converted and 4 original centers were dissolved in the past 12 months). Conversions were done in three waves because of the operational concern. Credit officers were initially unwilling to be responsible for more than one individual-liability center until successful repayment was observed.

\footnotetext{
${ }^{10}$ We also analyzed the impact of selection by comparing the performance of clients who joined three months before conversion to those that joined three months after. We found no significant differences in repayment, savings and loan size. Because the sample size of new entrants is rather small, and because the analysis is less clean as it relies a before versus after comparison (not an experimental comparison), we do not report these results.

${ }^{11}$ We run separate regressions for barangays with individual liability lenders and barangays with group liability lenders. The results do not differ significantly from those of Table 5 using all barangays and thus are not reported.
} 
In order to minimize the pressure on the credit officers, and to assess early results to ensure default did not rise substantially, the conversion was completed in three waves. ${ }^{12}$ We stratified the randomization by credit officer in order to ensure all credit officers had the same proportion of treatment (converted) and control centers. Since there were only 11 credit officers, the stratification ensured both a fair implementation across credit officers, and also an assignment to treatment that is not correlated with credit officer characteristics. In addition, we periodically checked with credit officers and conducted surprise visits to center meetings and clients' homes to confirm that converted centers had individual liability and that control centers had group liability.

\section{B. Data Collected}

We use data from five sources. First and most importantly, we use the Green Bank's full administrative data on repayment and savings, loan sizes and client retention rates for all 3,343 clients who were active members of the 169 centers at the time of the first randomization in August 2004, as well as the 8 new centers opened after August 2004. Second, we use data from an activity-based costing exercise that credit officers conducted, where for a given week, they had to keep a $\log$ of how they allocated their time across the different tasks they typically perform (e.g., attending meetings, assessing new clients, enforcing repayments, etc). Third, we use a baseline survey conducted in November 2004 regarding the social relationships in the treatment groups as well as control groups. Fourth, we use data from a follow-up survey on social networks, conducted in January 2006. Finally, we use a survey of clients conducted in November 2005 (over one year after the start of the experiment) designed to understand the observed differences between converted and control centers.

Table 1 presents summary statistics and some orthogonality checks that show that the randomization yielded observably similar treatment and control groups. As of August 2004, prior

\footnotetext{
${ }^{12}$ Note that increased default is not necessarily bad for the bank, since the bank cares about profits not merely default.
} 
to any center being converted, there are no detectable differences in the main outcome variables between treatment and control centers. ${ }^{13}$

\section{Empirical Strategy and Primary Results}

The experimental design described in Section III allows us to test several hypotheses that emerged above in the discussion of the relative merits of group versus individual liability. The primary goal is to measure the change in key variables that affect bank profitability, such as repayment, savings deposits held at the Green Bank by borrowers, loan size, and client retention and success attracting new clients. In the next section we examine further hypotheses about specific mechanisms such as selection, monitoring, enforcement, and changes in social networks.

Table 2 presents the primary results. Our empirical strategy takes into account the fact that not all centers were converted at the same time and that fifty percent remain in a control group throughout the study. The primary specifications are analyzed at the individual level, with standard errors clustered at the center level. The sample frame includes only clients that were borrowers at the time of each wave of the randomization. This allows us to focus analytically on the ex-post changes in behavior generated by group versus individual liability. We present the results of the three waves as if each were its own separate experiment (albeit sharing similar control groups ${ }^{14}$ ). This is done as such in order to account cleanly for any timing effects.

\footnotetext{
13 The orthogonality check verifies that the null hypothesis that there are no significant differences between the aggregated treatment and control groups cannot be rejected. When disaggregated, and examined wave by wave, the first wave of centers assigned to treatment are smaller than the other treatment centers and control centers. The primary specification controls for center-level fixed effects, so as long as this difference is not indicative of a difference in trends rather than levels, this imbalance is resolved in the fixed effect estimation model.

${ }^{14}$ They only differ if membership in the center changes between waves, if for instance individuals leave or join after one wave and before another.
} 
Specifically, we estimate a difference-in-difference model using OLS:

$\mathrm{y}_{\mathrm{igt}}=\alpha+\beta \mathrm{T}_{\mathrm{gt}}+\delta_{\mathrm{t}}+\theta_{\mathrm{g}}+\varepsilon_{\mathrm{igt}}$,

where the subscript $i$ refers to the individual, $g$ the group, and $t$ the time period, $T$ is an indicator variable if center $g$ is under an individual liability regime at time $t, \delta_{\mathrm{t}}$ are time fixed effects and $\theta_{\mathrm{g}}$ are center fixed effects. Thus, $\beta$ is the coefficient of interest.

Table 2 Columns 1, 2 and 3 show that the conversion to individual liability had no adverse (or advantageous) effect on client repayment. Not only is the point estimate close to zero, but most economically significant effects can be ruled out: the 95 percent confidence bound on default at the time of maturity (Column 2 ) is $+/-1.5 \%$ and 30 days after maturity (Column 3 ) is $+/-0.6 \%$. Thus, we do not find strong enough evidence to support the "social collateral" story of Besley and Coate (1995) that predicts higher repayment for group liability loans on average ${ }^{15}$ (however, as noted elsewhere, the "conversion" to individual liability does not remove all "social collateral" since repayment is still public, and someone may repay in order to protect their reputation in the community). Table 2 Column 4 shows that the savings behavior does not change after the conversion. One may have expected higher savings in individual liability since the savings deposits were not held as collateral for other people's loans, the expected return on savings is higher under individual liability (assuming there is some default in expectation under group liability).

Of course, the conversion to individual liability does imply both a reduction in peer pressure and an increase in bank pressure to repay. The empirical analysis addressed above concludes that the net effect is nil. To confirm that in fact the conversion was adhered to and group liability was not imposed in the treatment centers, we ask current members the reason why others

\footnotetext{
${ }^{15}$ Below, we will examine heterogeneous treatment effects where we will find evidence for social collateral mattering for those with stronger levels of social networks. On average, however, the net effect is that repayment is not higher under individual rather than group liability.
} 
dropped out. Appendix Table 1 shows these results. Under individual liability, individuals are less likely to be forced out of the center in net (column 1), but importantly Column 2 shows that individuals are less likely to forced out by their peers and more likely to be forced out by the credit officer.

We observe a (weak) reduction in loan size (Table 2, Column 6). This result is significant statistically only for the second wave of the experiment, although the point estimates for the other waves are similar in magnitude. The decrease is significant economically: a 958 peso reduction is $15.7 \%$ of the average loan size of 6,082 . The bank reported to us that this drop is due to mainly two reasons. First, individuals were withdrawing their individual savings (since they are no longer held in "communal" savings accounts as joint collateral) rather than borrowing in order to obtain the needed cash for their enterprise. Second, credit officers were stricter on loan sizes under the individual liability in order to protect the repayment performance of their centers. ${ }^{16}$

Table 3 shows the results for Table 2, but pooled in one regression. The results mimic those of Table 2, showing no effect on default and savings, and lower loan sizes. Note that these specifications include new entrants to the program and separate estimates of their treatment effects. We find that the lower loan sizes are driven by the pre-existing borrowers, implying that credit officers were being more careful with larger borrowers.

Table 4 uses a Cox proportional hazard model to estimate the likelihood of dropout in each given time period. We find a statistically insignificant effect for the sample as a whole. However, when we examine heterogeneous treatment effects we find that those with a prior history of missing payments and those with larger loan sizes are less likely to drop out. This implies that

\footnotetext{
${ }^{16}$ Unfortunately, data are not available on savings withdrawals in order to test the first hypothesis empirically. In support of the second reason, credit officers confirmed in interviews conducted in January 2006 that they were being more careful when determining loan sizes of clients in converted centers..
} 
while on average individual liability lowers drop out, it does so change the composition of the clients in the program. We will examine the net effect on profitability below.

Table 5 examines the main outcomes at the center level. We estimate the following specifications using OLS:

(1) $\mathrm{y}_{\mathrm{gt}}=\alpha+\beta \mathrm{T}_{\mathrm{gt}}+\delta_{\mathrm{t}}+\theta_{\mathrm{g}}+\varepsilon_{\mathrm{gt}}$,

where $y_{g t}$ is either the proportion of missed weeks, center size, retention rate, ${ }^{17}$ new accounts, number of dropouts or center dissolution for center $\mathrm{g}$ at time $\mathrm{t}, \delta_{\mathrm{t}}$ is an indicator variable equal to one for time period $\mathrm{t}$ (time fixed effect), $\theta_{\mathrm{g}}$ is a center fixed effect, and $\mathrm{T}_{\mathrm{gt}}$ is an indicator variable equal to one if group $g$ at time $t$ had been converted to individual liability. The time period is three months. The coefficient of interest is $\beta$. We test whether the liability rule matters by examining whether the coefficient $\beta$ is significantly different from zero. Notice that we use information from all clients who belonged at some point to the center between August 2004 and January 2005...

We find that individual liability is much better at attracting new clients (Column 4), leading to larger centers (Column 2) and that individual liability makes existing centers $10 \%$ points less likely to be dissolved (Column 6).

\section{Additional Results on Specific Mechanisms}

We now turn to three sets of auxiliary data. First, we examine the results of two activitybased costing exercises completed by the credit officers in order to measure the change in their allocation of their time across centers. Second, we examine the results of a client follow-up survey conducted in November 2005 (over one year after the initial conversion) on clients in both the treatment and control groups. This survey includes several questions intended to tell us more about three possible mechanisms that could be influenced by the liability structure: center activities, selection and the flow of information (monitoring). The survey was conducted during center

\footnotetext{
${ }^{17}$ The retention rate between $t$ and $t+1$ is defined as the percentage of clients at $t$ that are still clients at $t+1$.
} 
meetings and was administered to a sample of active members, including individuals who were members at the time of the conversion as well as new clients who entered afterwards. ${ }^{18}$ Third, we use social network data collected before the intervention and again one year later to examine the impact on social networks, as well as heterogeneous treatment effects for groups with different preexisting levels of social networks.

\section{A. Lender Costs: Activity-Based Costing Exercise}

It is important from a sustainability perspective to examine the complete impact on the lender of such a change from group to individual liability. If the lender spends more money on credit officer labor in order to screen, monitor and enforce loans then this is a necessary component of the analysis. In order to evaluate to what extent this was true, we conducted two activity-based costing exercises in which each credit officer kept a detailed diary of all activities for one week. We then attributed their activities to either repayment (preparing for center meetings plus collection and processing of repayments outside of the meetings), center meeting, monitoring, enforcement and/or re-loan activities. Table 6 reports these results. We find no statistically significant differences in the way credit officers allocated their time, and furthermore the point estimates are actually the opposite of what one may have expected on enforcement. On approval and processing of new loans (Column 7), credit officers do spend more time under individual liability, although again this result is not statistically significant.

\section{B. Center Activities}

The client follow-up survey asked questions about center penalties for missing meetings, leaving early and missing payments as well as various activities such as anniversary, Christmas and snacks during the meeting. Table 7 reports changes in penalties (columns 1 and 2) and activities between

\footnotetext{
${ }^{18}$ Since meeting attendance is compulsory, we should not be concerned with having a bias sample of survey respondents. In any event, we compared past repayment between respondents and non-respondents in converted and control centers and found no statistical differences across samples (largest t-stat is 0.82 ).
} 
treatment and control centers. We find that treatment centers impose lower penalties, possibly because meetings run smoother now that there is less need to enforce peer pressure among clients. However, the conversion to group liability may have resulted in lower center cohesion as evidenced by the lower probability of social events (not significant) and the lower amount spent (significant for Christmas parties).

\section{Selection and Monitoring}

Four sets of analysis provide insight into the changes in the selection of clients and monitoring resulting from the change in liability. We asked each member how well they knew the new members that had joined the center since intervention began. Table 8 Columns 1 and 2 show these results. We find that the prior members are more likely to know new members well under individual liability than under group liability. This is striking, given the typical assumption that group lending programs encourage peers to screen each other. However, this is consistent with evidence that the depth of family relations within a group is correlated with default (Ahlin and Townsend 2005). Under individual liability, peers no longer fear the acrimony of having to punish someone close to them if there is default, and hence are more willing to invite in their closest friends and family. New members, on the other hand, are less likely to know the other new members. Since new members are typically not the ones who bring in new members, this indicates that groups are making fewer group decisions on whom to admit and instead individuals are inviting their close friends or family. Thus prior members are closer to the new members, and new members are more distant to the other new members. This is also consistent with the fact that new members in treatment centers are less concerned with screening and learning about other new clients. 
Second, we examine how well individuals know the "type" of the other members in the group. We report these results in Table 8 Columns 3-12. We asked each individual four questions: (1) What is the business of person X? (Columns 3 and 4), (2) How many weekly installments did person X miss over the past three months? (Columns 5 through 8), (3) Did person X miss any payments over the past three months? (Columns 9 and 10), and (4) Do you think person X will miss some payments over the next three months? (Columns 11 and 12). We do not find any change in ability to report the peers' businesses, but we do find lower levels of ability to report who has missed payments (hence evidence of reduced monitoring) and lower levels of ability to predict who will or will not default. Again, this is evidence of lower monitoring, since it implies individuals are less informed about the status of each other's business and lives and, hence, their ability to repay their loans.

The third result on selection looks at the distribution of ability to pay (rather than observed repayment) among existing clients and new clients in treatment and control centers. We asked how many times in the last 3 months they had difficulty in repaying the loan, regardless of whether or not they ended up completely repaying the loan installment. We believe that this measure (rather than observed default) captures the combination of "type" (selection) and ex-ante moral hazard (effort) that is generated from group versus individual liability because being in default is only observed when the member does not have enough cash and other members fail to contribute toward the installment. Since side contributions are compulsory in control centers but only voluntary in treatment centers, differences in default rate would come from not only different ability to repay but also different contribution levels from fellow group members.

In theory, there are two groups of borrowers that would join only individual liability centers. On one end of the distribution, bad risks would be screened out and rejected from group 
liability centers but could be accepted in individual liability centers if the bank is unable to screen as effectively. On the other end of the distribution, good risks may have little to gain and much to lose from the implicit risk-sharing agreement imposed by group liability. They decide not to join group liability centers because they fear being forced to help other members repay more frequently than they will receive help. The left panel of Figure 1 plots the distribution of the number of times new clients had difficulty making their payments, while the right panel plots the same distributions for baseline clients (those borrowing at the time of conversion, hence screened under group liability). Interestingly, the distributions of baseline clients in treatment and control centers look alike, but the distribution of new clients in treatment centers is more concentrated around zero than that for control centers. This suggests that good risks were reluctant to join group liability centers but do so after these centers are converted to individual liability. We do not find evidence of bad risks also joining individual liability centers. A test of equal variances between the distribution and control centers is significant for new clients and not significant for baseline clients.

The fourth and last result on selection focuses on the interaction between demand and the competitive setting. Did individuals increase or decrease their borrowing with other lenders after the Green Bank converted to individual liability? The results are reported in Table 9, where it is clear that the answer depends entirely on whether the other lender is a group or an individual liability lender. If we restrict the analysis to barangays in which the competition is engaged in group lending, then we find that Green Bank clients are more likely to borrow from them after their group is switched to individual liability. This indicates perhaps that some individuals prefer group liability (perhaps for the risk-sharing component of group liability) and hence when the group liability is removed they remain with the Green Bank but also then seek a loan from a separate group liability program. On the other hand, when the competition only offers individual liability, 
we see a reduction in the likelihood that individuals seek a loan (although this result is only significant in the tobit specification on loan size, and has a p-value of 0.17 for the probit specification). This indicates, again, that individuals prefer one or the other type of liability: when the Green Bank switches to individual liability, individuals who prefer it are more satisfied, and individuals who prefer group liability seek supplementary loans from other group lending programs.

\section{Heterogeneous Treatment Effects}

The shift to individual liability may have worked better (or worse) in groups with different levels of preexisting social networks. If social collateral keeps repayment high, then "releasing" the collateral by converting to individual liability may lead individuals with higher social capital to have lower repayment rates. On the other hand, if individuals have higher social capital because of their stronger and more trustworthy characters, then the shift to individual liability should be less likely to influence their decision to repay (since they are a "trustworthy" type, perhaps irrespective of whether social collateral is at stake or not). We test these hypotheses in Table 10 by interacting treatment with one of various social network measures. We categorize the social network channels as either "knowledge" or "trust". "Knowledge" includes: family, friend since childhood, buys products or services, or visits once a week for social purposes. "Trust" includes has given a loan to the other person outside of the Green Bank program, voluntarily helped them pay their Green Bank loan, or turns to this person for advice or help.

We then examine two repayment measures: proportion of missed weekly payments, and percentage of loan past due at the time of maturity. Note from earlier that missing weekly payments could be a sign of being trusted, not of being delinquent, since trusted individuals are 
given more latitude during the term of their loan, in the case of a bad week or shock. Default at the end of the cycle, however, is unequivocally avoided.

We find that proportion of missed weeks is overall lower under individual liability (just as reported in Table 2), but is statistically significant for those with stronger social networks. If those with stronger social networks are given more latitude under group liability because others are able to vouch for their intent to repay the following week, the shift to individual liability reduces the frequency of missing payments since this luxury is no longer available. This is similar to Karlan (2005), which uses data from a group lending program in Peru and finds evidence that those with higher social capital are able to default on loans and remain in the lending circle, whereas those with lower social capital are typically forced out after default.

Eventual default, however, is lower under individual liability for those with stronger social networks. This may be an indication that those identified as having stronger social networks are more trustworthy, hence the shift to individual liability has no adverse effect on their likelihood of repaying. Those with weaker social networks, however, are in fact more likely to go into default on their loan under individual liability, relative to those who remain in group liability. An alternative hypothesis is that those with stronger social networks must repay their loan in both setups in order to protect their social networks. Those with weaker social networks have less to lose (less social collateral, in the model of Besley and Coate (1995)), and hence the shift to individual liability generates higher default.

\section{E. Changes in Social Networks}

Next, we examine the results of the follow-up social network survey. In Table 11 we show these results. As we have both baseline and follow-up data on social networks, we are able to employ a difference-in-difference empirical specification. We find only one social network 
channel to have changed: likelihood to help another person with a side-loan in order to help her make her loan payment. Social networks should change under individual liability for many reasons. First, with fewer incentives to monitor, they may find the quantity of interaction falls. On the other hand, the quality of the interaction may increase since they no longer have to pressure each other to repay. From selection, as found earlier, we find groups more connected because individuals are inviting closer friends and family to join the center. However, in net, we find no significant impacts on social networks, barring the reduction in likelihood to make side-loans to each other.

\section{Conclusion}

The choice of group or individual liability is perhaps one of the most basic questions lenders make in the design of loan products in credit markets for the poor. Despite the importance of this decision, past empirical research on group and individual liability has not provided policymakers and institutions the clean evidence needed to determine the relative merits of the two methodologies. In this study, we use a randomized control trial to evaluate the impact of group liability on the performance of clients and the profitability for the lending institution. Naturally, these are the results over one year, from one lender in one region of the Philippines. The results are striking, however, in two respects. First, we find that individual liability compared to group liability leads to no change in repayment but is better at attracting new clients and keeping existing ones. Second, we do find statistically significant evidence of some of the mechanisms discussed in the group liability literature, such as screening and monitoring, but we simply do not find that it adds up in an economically meaningful way to higher (or lower) default.

Our findings are consistent with the work of Greif (1994) in a rather different context. He suggests that collectivist societies, like joint liability institutions in our setting, are based on the 
ability to impose social sanctions to players that deviate from the agreed norms of conduct. But this requires a level of trust and knowledge among players that may hinder expansion of the set of players thus leaving efficient trades unrealized. A more individualistic society requires fewer exchanges of information among players and is thus able to grow faster. It does necessitate, however, well-functioning formal institutions to enforce contracts. In our context, shifting some of the burden from clients to credit officers strikes this balance successfully. The institutional enforcement is sufficient to recover loans without group liability, and the individual liability allows for more growth and outreach for the lender.

It is important to note that the primary experiment is on a sample of individuals who joined a group liability program. This has the advantage of allowing us to isolate moral hazard effects, but has the disadvantage of restricting our ability to predict whether individual liability programs can work when the selection occurs under individual liability. Furthermore, we cannot assess whether centers must achieve a certain age before the group liability can be successfully removed. Thus, while we contribute to understanding how such conversions work, it is also imperative to know whether centers can be sustainable if begun under individual liability.

In ongoing research with the Green Bank, we are working on an expansion of this program to new areas, and consequently will be testing whether the individual liability model will perform as well when groups are initially formed under individual liability. We also are introducing a hybrid design in which centers start as group liability but are told that conditional on successful repayment, they will convert to individual liability in the future.

In sum, the recent trend of microfinance institutions expanding their individual lending products (or in some cases, shifting from group liability to individual liability) should help deepen outreach and provide more flexible microfinance products for the poor. Our findings suggest that 
the innovators finding methods of lending individually (and more flexibly) to the poor are moving in the right direction. 


\section{References}

Adams, D. W. and J. R. Ladman (1979). "Lending to rural poor through informal groups: A promising financial innovation?" Savings and Development 2(3): 85-94.

Ahlin, C. and R. Townsend (2005). "Using Repayment Data to Test Across Models of Joint Liability Lending." Working Paper.

Ahlin, C. and R. Townsend (2006). "Selection into and across credit contracts: theory and field research." Journal of Econometrics forthcoming.

Armendariz de Aghion, B. and J. Morduch (2005). The Economics of Microfinance, MIT Press.

Besley, T. J. and S. Coate (1995). "Group Lending, Repayment Incentives and Social Collateral." Journal of Development Economics 46(1): 1-18.

Desai, B. M. (1983). Group lending in rural areas. Rural financial markets in developing countries: Their use and abuse. J. D. von Pischke, D. W. Adams and G. Donald. Baltimore, Md., U.S.A., Johns Hopkins University Press: 284-288.

Ghatak, M. (1999). "Group lending, local information and peer selection." Journal of Development Economics 60(1): 27-50.

Karlan, D. S. (2005). "Social Connections and Group Banking." Yale University Economic Growth Center Discussion Paper 913.

Karlan, D. S. and J. D. Zinman (2006). "Observing Unobservables: Identifying Information Asymmetries with a Consumer Credit Field Experiment." Yale University Economic Growth Center Discussion Paper 911.

Madajewicz, M. (2003). "Capital for the Poor: The Effect of Wealth on the Optimal Credit Contract." Columbia University Working paper.

Matin, I. (1997). "Repayment performance of Grameen Bank borrowers: The 'unzipped' state." Savings and Development 4.

Microcredit Summit Campaign (2005). "State of the Microcredit Summit Campaign Report 2005." http://www.microcreditsummit.org/pubs/reports/socr02 en.pdf.

Montgomery, R. (1996). "Disciplining or protecting the poor? Avoiding the social costs of peer pressure in micro-credit schemes." Journal of International Development 8(2): 289-306.

Morduch, J. (1999). "The Microfinance Promise." Journal of Economic Literature 37(4): 15691614.

Rahman, A. (1999). "Microcredit Initiatives for Equitable and Sustainable Development Who Pays?" World Development 27(1).

Rai, A. and T. Sjostrom (2004). "Is Grameen Lending Efficient? Repayment Incentives and Insurance in Village Economies." Review of Economic Studies 71(1): 217-234.

Sadoulet, L. (1997). "The Role of Mutual Insurance in Group Lending." Department of Economics, Princeton University, manuscript.

Woolcock, M. (1999). "Learning from failures in microfinance: What unsuccessful cases tell us about how group-based programs work." The American Journal of Economics and Sociology 58: 17-42.

Wydick, B. (1999). "Can Social Cohesion be Harnessed to Repair Market Failures? Evidence from Group Lending in Guatemala." Economic Journal 109(457): 463-475. 


\section{Figure 1: Kernel Density: Number of weeks that clients had difficulty repaying}

\section{3 months prior to the November Survey, Center average}

The left panel shows the kernel densities of the center average of the number of weeks in difficulty repaying over the three months prior of the survey in November 2005 for treatment centers (red) and control centers (blue). The right panel plots the same distribution for baseline clients. The sample includes clients who attended the center meeting when the survey was conducted.

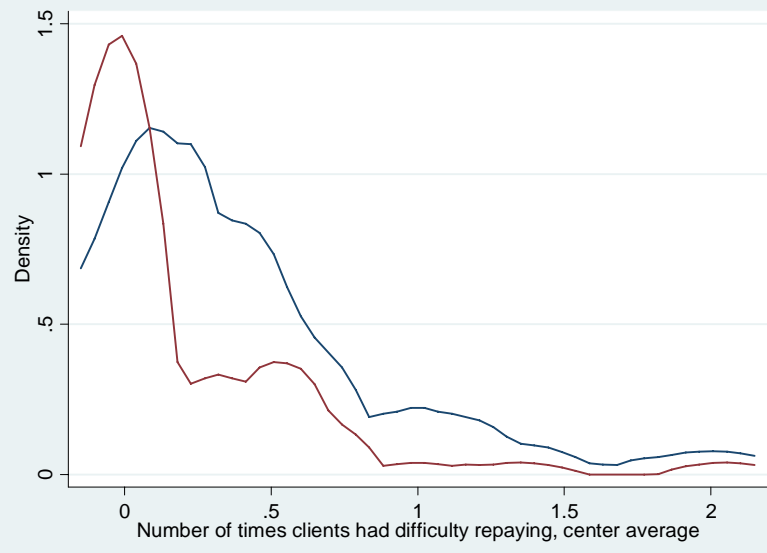

New Clients

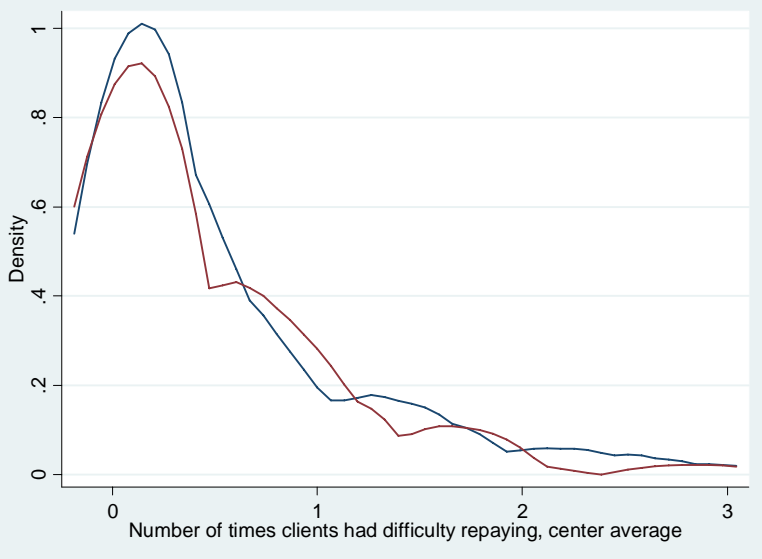

Baseline Clients 
Table 1: Summary Statistics

\begin{tabular}{|c|c|c|c|c|c|c|c|}
\hline & \multirow{2}{*}{$\begin{array}{l}\text { All } \\
(1) \\
\end{array}$} & \multirow{2}{*}{$\begin{array}{c}\text { Control } \\
(2) \\
\end{array}$} & \multicolumn{4}{|c|}{ Treatment } & \multirow{2}{*}{$\begin{array}{c}\text { T-stat } \\
\text { Control vs } \\
\text { Treatment } \\
(7) \\
\end{array}$} \\
\hline & & & $\begin{array}{c}\text { All Waves } \\
(3) \\
\end{array}$ & $\begin{array}{c}\text { Wave } 1 \\
(4) \\
\end{array}$ & $\begin{array}{c}\text { Wave } 2 \\
(5)\end{array}$ & $\begin{array}{c}\text { Wave } 3 \\
\text { (6) }\end{array}$ & \\
\hline \multicolumn{8}{|l|}{ A. Center Performance, pre-intervention } \\
\hline Total number of accounts & $\begin{array}{l}20.512 \\
(0.925)\end{array}$ & $\begin{array}{l}20.276 \\
(1.261)\end{array}$ & $\begin{array}{l}20.253 \\
(1.367)\end{array}$ & $\begin{array}{l}23.600 \\
(4.017)\end{array}$ & $\begin{array}{l}18.333 \\
(2.653)\end{array}$ & $\begin{array}{l}21.218 \\
(1.742)\end{array}$ & 0.774 \\
\hline $\begin{array}{l}\text { Proportion of missed weeks over cycle } \\
\text { (May-Aug 2004) }\end{array}$ & $\begin{array}{c}0.070 \\
(0.011)\end{array}$ & $\begin{array}{c}0.065 \\
(0.011)\end{array}$ & $\begin{array}{c}0.083 \\
(0.019)\end{array}$ & $\begin{array}{c}0.039 \\
(0.024)\end{array}$ & $\begin{array}{c}0.042 \\
(0.018)\end{array}$ & $\begin{array}{c}0.099 \\
(0.031)\end{array}$ & 0.926 \\
\hline $\begin{array}{l}\text { Retention } \\
\quad \text { (May-Aug 2004) }\end{array}$ & $\begin{array}{c}0.904 \\
(0.011)\end{array}$ & $\begin{array}{c}0.901 \\
(0.016)\end{array}$ & $\begin{array}{c}0.906 \\
(0.015)\end{array}$ & $\begin{array}{c}0.933 \\
(0.020)\end{array}$ & $\begin{array}{c}0.930 \\
(0.022)\end{array}$ & $\begin{array}{c}0.892 \\
(0.022)\end{array}$ & 0.758 \\
\hline Observations & 169 & 89 & 80 & 11 & 24 & 45 & \\
\hline \multicolumn{8}{|c|}{ B. Individual-level Performance, pre-intervention } \\
\hline Loan amount in August 2004 & $\begin{array}{c}6082.074 \\
(64.944)\end{array}$ & $\begin{array}{c}6123.237 \\
(90.359)\end{array}$ & $\begin{array}{c}6036.125 \\
(93.072)\end{array}$ & $\begin{array}{l}5165.354 \\
(180.301)\end{array}$ & $\begin{array}{l}5778.497 \\
(193.300)\end{array}$ & $\begin{array}{l}6399.568 \\
(125.040)\end{array}$ & 0.503 \\
\hline Number of active clients, August 2004 & 3,308 & 1,744 & 1564 & 231 & 399 & 972 & \\
\hline
\end{tabular}

Standard errors in parentheses. 52 pesos = US\$1. t-statistics reported in column (7) is the probability of (column (2) - column (3)) being zero. 
Table 2: Cycle-level Impact on Default, Savings, and Loan Size by Conversion Waves

OLS

Sample frame: Baseline clients only

\begin{tabular}{|c|c|c|c|c|c|}
\hline Dependent Variable: & $\begin{array}{l}\text { Proportion of } \\
\text { missed weeks } \\
\text { (1) }\end{array}$ & $\begin{array}{c}\text { Percentage of } \\
\text { past due balance, } \\
\text { at maturity date } \\
\text { (2) }\end{array}$ & $\begin{array}{l}\text { Past due balance, } \\
30 \text { days past } \\
\text { maturity date } \\
\text { (binary) } \\
\text { (3) }\end{array}$ & $\begin{array}{l}\text { Total excess } \\
\text { savings } \\
(4)\end{array}$ & $\begin{array}{c}\text { Loan Size } \\
\text { (5) }\end{array}$ \\
\hline \multicolumn{6}{|l|}{ Panel A: Wave 1 Conversion (Aug 2004) } \\
\hline Treatment & $\begin{array}{c}-0.017 \\
(0.040)\end{array}$ & $\begin{array}{c}0.051 \\
(0.077)\end{array}$ & $\begin{array}{c}0.004 \\
(0.003)\end{array}$ & $\begin{array}{c}9.679 \\
(69.493)\end{array}$ & $\begin{array}{l}-853.041 \\
(726.291)\end{array}$ \\
\hline Constant & $\begin{array}{c}0.916^{* * *} \\
(0.006)\end{array}$ & $\begin{array}{c}0.131 * * * \\
(0.021)\end{array}$ & $\begin{array}{c}0.000 \\
(0.000)\end{array}$ & $\begin{array}{c}44.712^{* * *} \\
(16.487)\end{array}$ & $\begin{array}{c}2,490.513^{* * *} \\
\quad(84.169)\end{array}$ \\
\hline Mean of dependent variable & 0.078 & 0.133 & 0.001 & 272.561 & 6395.923 \\
\hline Observations & 9027 & 9027 & 9027 & 8097 & 9027 \\
\hline Number of group(branch center) & 97 & 97 & 97 & 97 & 97 \\
\hline R-squared & 0.07 & 0.01 & 0.01 & 0.01 & 0.17 \\
\hline \multicolumn{6}{|l|}{ Panel B: Wave 2 Conversion (Nov 2004) } \\
\hline Treatment & $\begin{array}{c}0.017 \\
(0.014)\end{array}$ & $\begin{array}{c}0.070 \\
(0.113)\end{array}$ & $\begin{array}{c}0.002 \\
(0.003)\end{array}$ & $\begin{array}{l}-32.080 \\
(29.751)\end{array}$ & $\begin{array}{c}-962.557 * * \\
(418.074)\end{array}$ \\
\hline Constant & $\begin{array}{c}0.831^{* * * *} \\
(0.016)\end{array}$ & $\begin{array}{c}0.188 * * * \\
(0.042)\end{array}$ & $\begin{array}{c}0.002^{* * *} \\
(0.001)\end{array}$ & $\begin{array}{c}111.848^{* * *} \\
(12.333)\end{array}$ & $\begin{array}{l}354.202^{*} \\
(206.981)\end{array}$ \\
\hline Mean of dependent variable & 0.075 & 0.179 & 0.002 & 271.560 & 6314.152 \\
\hline Observations & 10557 & 10557 & 10557 & 9434 & 10557 \\
\hline Number of group(branch center) & 112 & 112 & 112 & 112 & 112 \\
\hline R-squared & 0.08 & 0.01 & 0.01 & 0.01 & 0.14 \\
\hline \multicolumn{6}{|l|}{ Panel C: Wave 3 Conversion (May 2005) } \\
\hline Treatment & $\begin{array}{l}-0.029 \\
(0.022)\end{array}$ & $\begin{array}{c}0.029 \\
(0.091)\end{array}$ & $\begin{array}{c}0.003 \\
(0.003)\end{array}$ & & $\begin{array}{l}-407.574 \\
(343.917)\end{array}$ \\
\hline Constant & $\begin{array}{c}0.008 \\
(0.007)\end{array}$ & $\begin{array}{l}0.094^{*} \\
(0.051)\end{array}$ & $\begin{array}{c}0.002^{* * *} \\
(0.000)\end{array}$ & & $\begin{array}{c}2,724.253^{* * * *} \\
\quad(88.509)\end{array}$ \\
\hline Mean of dependent variable & 0.076 & 0.131 & 0.001 & & 6345.303 \\
\hline Observations & 14189 & 14189 & 14189 & & 14189 \\
\hline Number of group(branch center) & 134 & 134 & 134 & & 134 \\
\hline R-squared & 0.08 & 0.01 & 0.01 & & 0.12 \\
\hline
\end{tabular}

Robust standard errors clustered by lending centers in parentheses, * significant at $10 \%$; ** significant at $5 \%$; ** significant at 1\%. All regressions use fixed effect for lending centers and time. Proportion of missed weeks is calculated by the number of weeks in which the client did not make the full installment divided by the number of installments. Savings data are only analyzed up to September 2005 because systematic savings policy changes for control centers occurred in September 2005 which effectively required higher savings in control centers than treatment centers. Treatment variable is one if the loan cycle ends after the conversion in treatment centers; zero otherwise. 
Table 3: Cycle-level Impact on Default, Savings, and Loan Size, All waves combined Sample frame: All clients (both baseline and new clients)

\begin{tabular}{|c|c|c|c|c|c|}
\hline Dependent Variable: & $\begin{array}{l}\text { Proportion of } \\
\text { missed weeks } \\
\text { (1) }\end{array}$ & $\begin{array}{l}\text { Percentage of past } \\
\text { due balance, at } \\
\text { maturity date } \\
\text { (2) }\end{array}$ & $\begin{array}{l}\text { ast due balance, } \\
30 \text { days past } \\
\text { maturity date } \\
\text { (binary) } \\
\text { (3) }\end{array}$ & $\begin{array}{c}\text { Total excess } \\
\text { savings (pesos) } \\
(4)\end{array}$ & $\begin{array}{c}\text { Loan Size } \\
\text { (pesos) } \\
(5)\end{array}$ \\
\hline Treatment & $\begin{array}{l}-0.009 \\
(0.016)\end{array}$ & $\begin{array}{l}-0.146 \\
(0.106)\end{array}$ & $\begin{array}{l}-0.001 \\
(0.002)\end{array}$ & $\begin{array}{l}-19.397 \\
(22.184)\end{array}$ & $\begin{array}{c}-620.800^{* *} \\
(264.535)\end{array}$ \\
\hline New member after Aug 04 & $\begin{array}{l}-0.016 \\
(0.010)\end{array}$ & $\begin{array}{l}-0.067 \\
(0.095)\end{array}$ & $\begin{array}{l}-0.001 \\
(0.001)\end{array}$ & $\begin{array}{l}-23.194 \\
(21.267)\end{array}$ & $\begin{array}{c}-3,405.221^{* * * *} \\
(257.466)\end{array}$ \\
\hline New member after Nov 04 & $\begin{array}{l}-0.008 \\
(0.014)\end{array}$ & $\begin{array}{l}-0.057 \\
(0.202)\end{array}$ & $\begin{array}{l}-0.001 \\
(0.003)\end{array}$ & $\begin{array}{c}23.726 \\
(28.997)\end{array}$ & $\begin{array}{c}-964.930 * * * \\
(321.448)\end{array}$ \\
\hline New member after May 05 & $\begin{array}{c}-0.049 * * \\
(0.019)\end{array}$ & $\begin{array}{c}0.135 \\
(0.470)\end{array}$ & $\begin{array}{l}-0.001 \\
(0.009)\end{array}$ & $\begin{array}{l}-67.756 \\
(44.004)\end{array}$ & $\begin{array}{c}-1,542.772 * * * \\
(381.606)\end{array}$ \\
\hline Treatment x New member after Aug 04 & $\begin{array}{c}0.003 \\
(0.018)\end{array}$ & $\begin{array}{c}0.788 \\
(0.527)\end{array}$ & $\begin{array}{c}0.011 \\
(0.008)\end{array}$ & $\begin{array}{c}41.056 \\
(37.712)\end{array}$ & $\begin{array}{c}975.684 * * * \\
(334.453)\end{array}$ \\
\hline Treatment x New member after Nov 04 & $\begin{array}{l}-0.004 \\
(0.023)\end{array}$ & $\begin{array}{l}-0.792 \\
(0.513)\end{array}$ & $\begin{array}{l}-0.013 \\
(0.008)\end{array}$ & $\begin{array}{c}57.082 \\
(47.004)\end{array}$ & $\begin{array}{l}-775.486^{*} \\
(422.484)\end{array}$ \\
\hline Treatment x New member after May 05 & $\begin{array}{c}0.051 \\
(0.038)\end{array}$ & $\begin{array}{c}0.194 \\
(0.624)\end{array}$ & $\begin{array}{c}0.009 \\
(0.016)\end{array}$ & $\begin{array}{c}-4.612 \\
(71.083)\end{array}$ & $\begin{array}{c}518.325 \\
(473.306)\end{array}$ \\
\hline Constant & $\begin{array}{c}0.624^{* * * *} \\
(0.218)\end{array}$ & $\begin{array}{c}0.124 * * * \\
(0.027)\end{array}$ & $\begin{array}{c}0.001^{* * *} \\
(0.001)\end{array}$ & $\begin{array}{c}167.416 * * * \\
(60.982)\end{array}$ & $\begin{array}{c}1,176.215^{* *} \\
(476.488)\end{array}$ \\
\hline Mean of dependent variable & 0.080 & 0.184 & 0.002 & 253.021 & 6154.993 \\
\hline Observations & 18217 & 18217 & 18217 & 18122 & 18217 \\
\hline R-squared & 0.06 & 0.01 & 0.01 & 0.01 & 0.18 \\
\hline
\end{tabular}

Robust standard errors clustered by lending center in parentheses, * significant at 10\%; ** significant at 5\%; *** significant at $1 \%$. All regressions use fixed effect for centers and time. Proportion of missed weeks is calculated by the number of weeks in which the client did not make the full installment divided by the number of installments. Savings data only analyzed up to September 2005 because systematic savings policy changes for control centers occurred in September 2005 which effectively required higher savings in control centers than treatment centers. Treatment variable is one if the loan cycle ends after the conversion in treatment centers; zero otherwise. 
Table 4: Impact on Dropout

Cox proportional hazard model, failure $=$ dropout

Dependent Variable: Binary variable equal to one if the client has dropped out Sample frame: Baseline clients only

\begin{tabular}{|c|c|c|c|c|c|}
\hline Sample Frame: & $\begin{array}{l}\text { All } \\
\text { (1) }\end{array}$ & $\begin{array}{l}\text { Never missed } \\
\text { payment, pre } \\
\text { intervention } \\
(2)\end{array}$ & $\begin{array}{l}\text { Missed payment, } \\
\text { pre-intervention } \\
\text { (3) }\end{array}$ & $\begin{array}{l}\text { Loan size above } \\
\text { median } \\
(4)\end{array}$ & $\begin{array}{l}\text { Loan size below } \\
\text { median } \\
\text { (5) }\end{array}$ \\
\hline \multicolumn{6}{|l|}{ Panel A: Wave 1} \\
\hline Treatment & $\begin{array}{c}0.841 \\
(0.120)\end{array}$ & $\begin{array}{c}0.811 \\
(0.154)\end{array}$ & $\begin{array}{c}0.881 \\
(0.125)\end{array}$ & $\begin{array}{c}0.760^{* *} \\
(0.101)\end{array}$ & $\begin{array}{c}0.866 \\
(0.150)\end{array}$ \\
\hline Observations & 2230 & 767 & 1463 & 1011 & 1219 \\
\hline \multicolumn{6}{|l|}{ Panel B: Wave 2} \\
\hline Treatment & $\begin{array}{c}1.051 \\
(0.158)\end{array}$ & $\begin{array}{c}0.980 \\
(0.188)\end{array}$ & $\begin{array}{c}1.132 \\
(0.206)\end{array}$ & $\begin{array}{c}0.926 \\
(0.196)\end{array}$ & $\begin{array}{c}1.089 \\
(0.185)\end{array}$ \\
\hline Observations & 2585 & 972 & 1613 & 1188 & 1397 \\
\hline \multicolumn{6}{|l|}{ Panel C: Wave 3} \\
\hline Treatment & $\begin{array}{c}0.842 \\
(0.100)\end{array}$ & $\begin{array}{c}1.111 \\
(0.208)\end{array}$ & $\begin{array}{l}0.790 * \\
(0.107)\end{array}$ & $\begin{array}{c}0.769 * \\
(0.110)\end{array}$ & $\begin{array}{c}0.929 \\
(0.150)\end{array}$ \\
\hline Observations & 2821 & 875 & 1946 & 1487 & 1334 \\
\hline
\end{tabular}

* significant at $10 \%$; ** significant at $5 \%$; ** significant at $1 \%$. The model estimated is the Cox proportional hazard. Reported are hazard ratios and standard errors in parentheses, calculated assuming within-center clustering. Lower hazard ratio $(<1)$ indicates that clients in Treatment centers stay longer in the program and that conversion into individual-liability is associated with lower likelihood of dropping out. 


\section{Table 5: Center-level Performance}

OLS

\begin{tabular}{lcccccc}
\hline \hline & $\begin{array}{c}\text { Proportion of } \\
\text { missed weeks } \\
(1)\end{array}$ & $\begin{array}{c}\text { Active } \\
\text { accounts } \\
(2)\end{array}$ & $\begin{array}{c}\text { Retention rate New accounts } \\
(3)\end{array}$ & $\begin{array}{c}\text { Number of } \\
\text { dropouts } \\
(4)\end{array}$ & $\begin{array}{c}\text { Dissolved } \\
\text { center } \\
(6)\end{array}$ \\
\hline \multirow{2}{*}{ Treatment } & & & & & & \\
& 0.006 & $1.826^{* *}$ & 0.015 & $1.190^{* *}$ & -0.119 & $-0.106^{*}$ \\
Constant & $(0.013)$ & $(0.762)$ & $(0.019)$ & $(0.486)$ & $(0.284)$ & $(0.059)$ \\
& $0.078^{* * *}$ & $17.866^{* * *}$ & $0.922^{* * *}$ & $1.553^{* * *}$ & $1.376^{* * *}$ & 0.109 \\
Observations & $(0.014)$ & $(1.203)$ & $(0.012)$ & $(0.354)$ & $(0.179)$ & $(0.067)$ \\
Number of centers & 1088 & 1498 & 1312 & 1294 & 1312 & 169 \\
R-squared & 169 & 169 & 169 & 169 & 169 & \\
\hline
\end{tabular}

Robust standard errors in parentheses, * significant at 10\%; ** significant at 5\%; *** significant at $1 \%$. Columns (1) through (5) use fixed effect for centers and time, and every center has an observation on each outcome for every three month between August 2003 and November 2005. Column (6) uses fixed effect for credit officers. Number of observations for column (1) is smaller because the value is missing if there is no account whose maturity date falls in a 
Table 6: Activity-Based Costing Analysis: Time Spent on Different Activities by Center

\begin{tabular}{|c|c|c|c|c|c|c|c|}
\hline \multicolumn{8}{|c|}{ OLS } \\
\hline & $\begin{array}{c}\text { Total Time } \\
\text { (1) }\end{array}$ & $\begin{array}{l}\text { Time on } \\
\text { repayment } \\
\text { activities } \\
\text { (2) }\end{array}$ & $\begin{array}{c}\text { Time on center } \\
\text { meeting } \\
\text { (3) }\end{array}$ & $\begin{array}{c}\text { Time on loan } \\
\text { monitoring } \\
\text { (4) }\end{array}$ & $\begin{array}{c}\text { Time on loan } \\
\text { enforcement } \\
\text { (5) }\end{array}$ & $\begin{array}{c}\text { Time on } \\
\text { following up } \\
\text { with delinquent } \\
\text { clients } \\
\text { (6) }\end{array}$ & $\begin{array}{c}\text { Time on reloan } \\
\text { (7) }\end{array}$ \\
\hline \multirow[t]{2}{*}{ Treatment } & 0.019 & 0.029 & -0.033 & -0.085 & -0.145 & -0.086 & 0.211 \\
\hline & $(0.268)$ & $(0.157)$ & $(0.086)$ & $(0.066)$ & $(0.087)$ & $(0.071)$ & $(0.143)$ \\
\hline \multirow[t]{2}{*}{ Constant } & $1.640 * *$ & $1.333^{* *}$ & $0.487 * *$ & 0.108 & 0.139 & 0.090 & -0.020 \\
\hline & $(0.267)$ & $(0.164)$ & $(0.089)$ & $(0.074)$ & $(0.097)$ & $(0.070)$ & $(0.120)$ \\
\hline Observations & 146 & 146 & 146 & 146 & 146 & 146 & 146 \\
\hline R-squared & 0.32 & 0.22 & 0.09 & 0.06 & 0.06 & 0.05 & 0.15 \\
\hline
\end{tabular}


Table 7: Center activities

Sample framework: Centers included in the follow-up social network survey in January 2006.

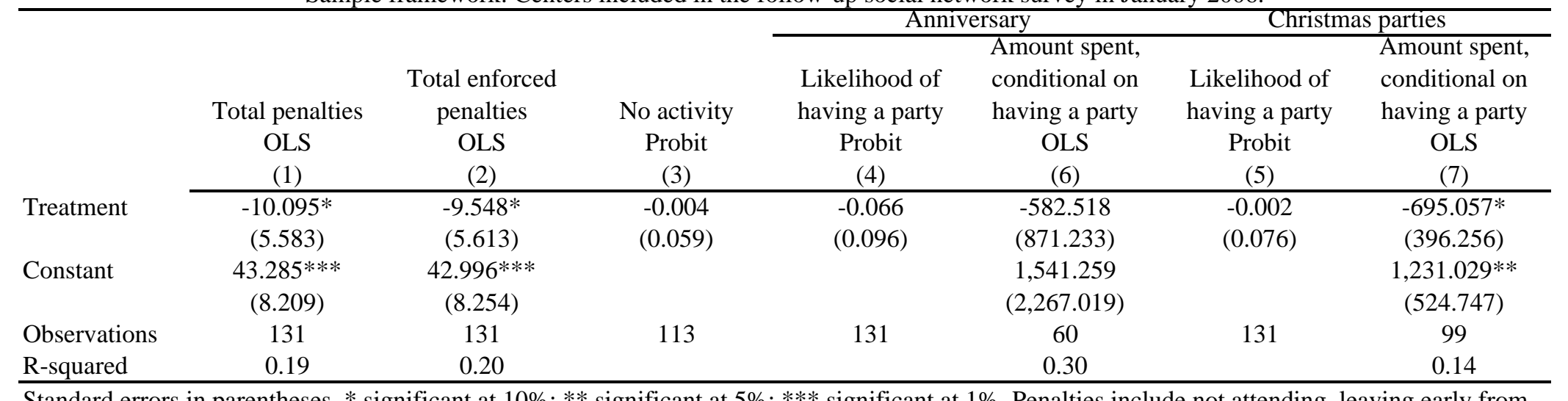

Standard errors in parentheses. * significant at 10\%; ** significant at 5\%; *** significant at $1 \%$. Penalties include not attending, leaving early from, being late to the meeting, and missing payments. 


\section{Table 8: Knowledge About Other Members of the Center}

Clients were asked about (a) how well they knew incoming members who joined the center, and

(b) other members' performances over three months prior to the survey

Sample Frame: Clients who were present at the survey which took place during a center meeting in November 2005

\begin{tabular}{|c|c|c|c|c|c|c|c|c|c|c|c|c|}
\hline \multirow{4}{*}{ Dependent Variable: } & \multicolumn{2}{|c|}{$\begin{array}{l}\text { Knowledge about new } \\
\text { members only }\end{array}$} & \multirow[b]{2}{*}{$\begin{array}{l}\text { Baseline } \\
\text { Clients }\end{array}$} & \multirow[b]{2}{*}{$\begin{array}{c}\text { New } \\
\text { Clients }\end{array}$} & \multirow[b]{2}{*}{$\begin{array}{c}\text { Baseline } \\
\text { Clients }\end{array}$} & \multicolumn{5}{|c|}{ Knowledge about all other members } & \multirow[b]{2}{*}{$\begin{array}{c}\text { Baseline } \\
\text { Clients }\end{array}$} & \multirow[b]{2}{*}{$\begin{array}{c}\text { New } \\
\text { Clients } \\
\end{array}$} \\
\hline & $\begin{array}{c}\text { Baseline } \\
\text { Clients }\end{array}$ & $\begin{array}{c}\text { New } \\
\text { Clients } \\
\end{array}$ & & & & $\begin{array}{l}\text { New } \\
\text { Clients }\end{array}$ & $\begin{array}{c}\text { Baseline } \\
\text { Clients } \\
\end{array}$ & $\begin{array}{c}\text { New } \\
\text { Clients } \\
\end{array}$ & $\begin{array}{l}\text { Baseline } \\
\text { Clients }\end{array}$ & $\begin{array}{c}\text { New } \\
\text { Clients }\end{array}$ & & \\
\hline & \multicolumn{2}{|c|}{$\begin{array}{c}\text { Knew the new member } \\
\text { well when they entered } \\
\text { the center }\end{array}$} & \multicolumn{2}{|c|}{ Knew Business } & \multicolumn{2}{|c|}{$\begin{array}{l}\text { Negative value of } \\
\text { difference between } \\
\text { reported and actual } \\
\text { amount of installment }\end{array}$} & \multicolumn{2}{|c|}{$\begin{array}{l}\text { Negative value of } \\
\text { difference between } \\
\text { reported and actual } \\
\text { number of defaults }\end{array}$} & \multicolumn{2}{|c|}{$\begin{array}{l}\text { Knew whether or not } \\
\text { the client defaulted }\end{array}$} & \multicolumn{2}{|c|}{ Predicted default } \\
\hline & $\begin{array}{c}\text { Ordered } \\
\text { probit } \\
(1) \\
\end{array}$ & $\begin{array}{c}\text { Ordered } \\
\text { probit } \\
(2) \\
\end{array}$ & $\begin{array}{c}\text { Probit } \\
(3)\end{array}$ & $\begin{array}{l}\text { Probit } \\
(4)\end{array}$ & $\begin{array}{l}\text { OLS } \\
(5)\end{array}$ & $\begin{array}{l}\text { OLS } \\
(6) \\
\end{array}$ & $\begin{array}{l}\text { OLS } \\
(7) \\
\end{array}$ & $\begin{array}{l}\text { OLS } \\
(8)\end{array}$ & $\begin{array}{c}\text { Probit } \\
(9)\end{array}$ & $\begin{array}{c}\text { Probit } \\
(10)\end{array}$ & $\begin{array}{c}\text { Probit } \\
(11) \\
\end{array}$ & $\begin{array}{c}\text { Probit } \\
(12) \\
\end{array}$ \\
\hline Treatment & $\begin{array}{c}0.310 * * * \\
(0.104)\end{array}$ & $\begin{array}{c}-0.272^{* * *} \\
(0.023)\end{array}$ & $\begin{array}{l}-0.000 \\
(0.019)\end{array}$ & $\begin{array}{c}0.018 \\
(0.025)\end{array}$ & $\begin{array}{l}-4.585 \\
(5.582)\end{array}$ & $\begin{array}{l}-1.970 \\
(6.363)\end{array}$ & $\begin{array}{l}-0.091 * \\
(0.048)\end{array}$ & $\begin{array}{c}-0.259 * * \\
(0.100)\end{array}$ & $\begin{array}{l}-0.018 \\
(0.019)\end{array}$ & $\begin{array}{l}-0.019 \\
(0.026)\end{array}$ & $\begin{array}{l}-0.018 \\
(0.024)\end{array}$ & $\begin{array}{c}-0.059 * * \\
(0.029)\end{array}$ \\
\hline Constant & & & $\begin{array}{c}0.524^{* * *} \\
(0.071)\end{array}$ & $\begin{array}{c}0.323^{* * *} \\
(0.086)\end{array}$ & $\begin{array}{c}101.385 * * * \\
(11.602)\end{array}$ & $\begin{array}{c}81.935 * * * \\
(12.856)\end{array}$ & $\begin{array}{c}-0.933^{* * *} \\
(0.123)\end{array}$ & $\begin{array}{c}-0.787 * * * \\
(0.184)\end{array}$ & $\begin{array}{c}0.716^{* * *} \\
(0.075)\end{array}$ & $\begin{array}{c}0.285 * * \\
(0.128)\end{array}$ & $\begin{array}{c}0.897 * * * \\
(0.026)\end{array}$ & $\begin{array}{c}0.888 * * * \\
(0.031)\end{array}$ \\
\hline Observations & 1693 & 971 & 4015 & 1908 & 2902 & 1376 & 4128 & 2178 & 4161 & 2194 & 3684 & 1926 \\
\hline R-squared & & & 0.06 & 0.08 & 0.03 & 0.06 & 0.29 & 0.19 & 0.12 & 0.15 & 0.11 & 0.09 \\
\hline
\end{tabular}

Robust standard errors clustered by respondents in parentheses, * significant at $10 \%$; $*$ significant at $5 \%$; $* *$ significant at $1 \%$. Marginal coefficients reported for the probit specifications. All regressions use fixed effect for credit officers. Dependent variable for regressions in columns (1) and (2) is a categorical variable for how well the respondent knew the new member before she joined the program; 0 if did not know at all, 1 if knew a little, 2 if knew well, 3 if knew very well. 
Table 9: Current Borrowing from Other Lenders

Sample Frame: Clients who were present at the survey which took place during a center meeting in November 2005

\begin{tabular}{|c|c|c|c|c|c|c|c|c|}
\hline \multirow{3}{*}{ Sample Frame: } & \multicolumn{4}{|c|}{ Barangays with NGOs offering group-liability loans only } & \multicolumn{4}{|c|}{ Barangays with Coops offering individual-liability loans only } \\
\hline & \multirow[b]{2}{*}{ Baseline Clients } & \multirow[b]{2}{*}{ New Clients } & \multirow[b]{2}{*}{ Baseline Clients } & \multirow[b]{2}{*}{ New Clients } & \multirow{2}{*}{$\begin{array}{c}\text { Baseline } \\
\text { Clients }\end{array}$} & \multicolumn{3}{|c|}{ Baseline } \\
\hline & & & & & & New Clients & Clients & New Clients \\
\hline \multirow[t]{3}{*}{ Dependent Variable: } & \multicolumn{2}{|c|}{ Has loan from competitor } & \multicolumn{2}{|c|}{ Loan size from competitor } & \multicolumn{2}{|c|}{ Has loan from competitor } & \multicolumn{2}{|c|}{ Loan size from competitor } \\
\hline & Probit & Probit & Tobit & Tobit & Probit & Probit & Tobit & Tobit \\
\hline & $(1)$ & $(2)$ & $(3)$ & $(4)$ & $(5)$ & $(6)$ & $(7)$ & $(8)$ \\
\hline \multirow[t]{2}{*}{ Treatment } & $0.062 *$ & -0.021 & $5,039.823 * * *$ & -455.887 & -0.049 & -0.028 & $-8,703.439 *$ & $-5,972.977$ \\
\hline & $(0.034)$ & $(0.051)$ & $(1,907.141)$ & $(1,650.910)$ & $(0.035)$ & $(0.029)$ & $(4,856.900)$ & $(4,435.156)$ \\
\hline \multirow[t]{2}{*}{ Constant } & 0.125 & 0.000 & $-16,047.552 * * *$ & $-41,404.006$ & $0.377 * *$ & 0.006 & $-34,524.886 * * *$ & $-74,270.657$ \\
\hline & $(0.105)$ & $(0.000)$ & $(4,455.048)$ & $(677,400.165)$ & $(0.174)$ & $(0.008)$ & $(7,756.664)$ & (1415746.981) \\
\hline Observations & 474 & 269 & 474 & 269 & 476 & 257 & 476 & 257 \\
\hline R-squared & 0.07 & 0.14 & & & 0.07 & 0.10 & & \\
\hline
\end{tabular}

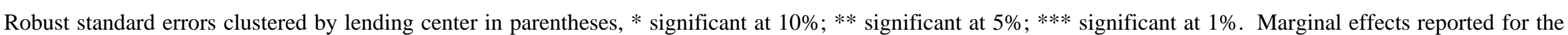

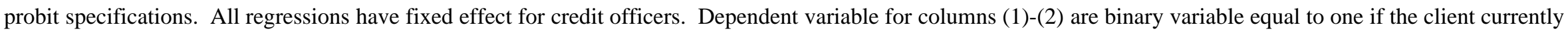
has loans from NGOs; that of columns (3)-(4) are binary variable equal to one if the client currently has loans from COOPs. 
Table 10: Impact of Social Network on Default

OLS

Sample Frame: Clients who were present at the meeting during the baseline social network baseline survey

\begin{tabular}{|c|c|c|c|c|c|c|c|c|c|c|}
\hline & \multicolumn{4}{|c|}{ Knowledge } & \multirow[b]{2}{*}{$\begin{array}{c}\text { Knowledge } \\
\text { index } \\
\text { (5) }\end{array}$} & \multicolumn{3}{|c|}{ Trust } & \multirow[b]{2}{*}{$\begin{array}{l}\text { Trust index } \\
\text { (9) }\end{array}$} & \multirow[b]{2}{*}{$\begin{array}{c}\text { All } \\
(10)\end{array}$} \\
\hline & $\begin{array}{l}\text { Family } \\
\text { (1) }\end{array}$ & $\begin{array}{l}\text { Friends } \\
\text { (2) }\end{array}$ & $\begin{array}{c}\text { Buy } \\
\text { products } \\
(3)\end{array}$ & $\begin{array}{l}\text { Visit once a } \\
\text { week } \\
\text { (4) }\end{array}$ & & $\begin{array}{l}\text { Given loan } \\
\text { (6) }\end{array}$ & $\begin{array}{c}\text { Voluntary } \\
\text { help } \\
\text { (7) }\end{array}$ & $\begin{array}{l}\text { Go for } \\
\text { advice } \\
\text { (8) }\end{array}$ & & \\
\hline Mean of social network out-degree measure & $\begin{array}{c}0.110 \\
(0.003) \\
\end{array}$ & $\begin{array}{c}0.045 \\
(0.002) \\
\end{array}$ & $\begin{array}{c}0.291 \\
(0.005) \\
\end{array}$ & $\begin{array}{c}0.131 \\
(0.004) \\
\end{array}$ & $\begin{array}{c}0.410 \\
(0.005) \\
\end{array}$ & $\begin{array}{c}0.036 \\
(0.002) \\
\end{array}$ & $\begin{array}{c}0.015 \\
(0.001) \\
\end{array}$ & $\begin{array}{c}0.071 \\
(0.003) \\
\end{array}$ & $\begin{array}{c}0.092 \\
(0.003) \\
\end{array}$ & $\begin{array}{c}0.418 \\
(0.005) \\
\end{array}$ \\
\hline \multicolumn{11}{|c|}{ Panel A: Dependent variable is proportion of missed weeks } \\
\hline Treatment & $\begin{array}{l}-0.036 \\
(0.023)\end{array}$ & $\begin{array}{l}-0.033 \\
(0.021)\end{array}$ & $\begin{array}{c}0.003 \\
(0.024)\end{array}$ & $\begin{array}{l}-0.029 \\
(0.022)\end{array}$ & $\begin{array}{c}0.000 \\
(0.024)\end{array}$ & $\begin{array}{l}-0.028 \\
(0.021)\end{array}$ & $\begin{array}{l}-0.035 \\
(0.021)\end{array}$ & $\begin{array}{l}-0.041 * \\
(0.024)\end{array}$ & $\begin{array}{l}-0.019 \\
(0.022)\end{array}$ & $\begin{array}{c}0.005 \\
(0.024)\end{array}$ \\
\hline Social network out-degree & $\begin{array}{l}-0.001 \\
(0.036)\end{array}$ & $\begin{array}{c}0.028 \\
(0.038)\end{array}$ & $\begin{array}{c}0.102 * * * \\
(0.036)\end{array}$ & $\begin{array}{l}0.067^{* *} \\
(0.034)\end{array}$ & $\begin{array}{c}0.077 * * * \\
(0.027)\end{array}$ & $\begin{array}{c}0.128 * * * \\
(0.049)\end{array}$ & $\begin{array}{c}0.103 \\
(0.078)\end{array}$ & $\begin{array}{c}0.008 \\
(0.038)\end{array}$ & $\begin{array}{l}0.108 * * \\
(0.043)\end{array}$ & $\begin{array}{c}0.082 * * * \\
(0.027)\end{array}$ \\
\hline Treatment x Social network out-degree & $\begin{array}{l}-0.023 \\
(0.047)\end{array}$ & $\begin{array}{l}-0.073 \\
(0.061)\end{array}$ & $\begin{array}{c}-0.114 * * \\
(0.055)\end{array}$ & $\begin{array}{l}-0.064 \\
(0.054)\end{array}$ & $\begin{array}{c}-0.080^{* *} \\
(0.040)\end{array}$ & $\begin{array}{l}-0.155^{*} \\
(0.081)\end{array}$ & $\begin{array}{l}-0.162 \\
(0.127)\end{array}$ & $\begin{array}{c}0.046 \\
(0.137)\end{array}$ & $\begin{array}{c}-0.145^{* *} \\
(0.060)\end{array}$ & $\begin{array}{c}-0.087 * * \\
(0.038)\end{array}$ \\
\hline Constant & $\begin{array}{c}0.085^{* * * *} \\
(0.026)\end{array}$ & $\begin{array}{c}0.083 * * * \\
(0.027)\end{array}$ & $\begin{array}{c}0.038 \\
(0.029)\end{array}$ & $\begin{array}{c}0.072^{* * *} \\
(0.027)\end{array}$ & $\begin{array}{c}0.044 \\
(0.029)\end{array}$ & $\begin{array}{c}0.071^{* * *} \\
(0.024)\end{array}$ & $\begin{array}{c}0.080^{* * *} \\
(0.025)\end{array}$ & $\begin{array}{c}0.084^{* * *} \\
(0.027)\end{array}$ & $\begin{array}{c}0.066 * * \\
(0.027)\end{array}$ & $\begin{array}{c}0.040 \\
(0.028)\end{array}$ \\
\hline Observations & 2688 & 2688 & 2688 & 2688 & 2688 & 2688 & 2688 & 2688 & 2688 & 2688 \\
\hline Number of center fixed effects & 157 & 157 & 157 & 157 & 157 & 157 & 157 & 157 & 157 & 157 \\
\hline R-squared & 0.02 & 0.02 & 0.03 & 0.02 & 0.02 & 0.02 & 0.02 & 0.02 & 0.02 & 0.02 \\
\hline \multicolumn{11}{|c|}{ Panel B: Dependent variable is percentage of past due balance at the maturity date } \\
\hline Treatment & $\begin{array}{c}0.419 \\
(0.285)\end{array}$ & $\begin{array}{c}0.194 \\
(0.321)\end{array}$ & $\begin{array}{c}0.488 \\
(0.431)\end{array}$ & $\begin{array}{l}0.493^{*} \\
(0.297)\end{array}$ & $\begin{array}{c}0.728 \\
(0.562)\end{array}$ & $\begin{array}{l}0.466^{*} \\
(0.272)\end{array}$ & $\begin{array}{c}0.279 \\
(0.262)\end{array}$ & $\begin{array}{c}0.038 \\
(0.505)\end{array}$ & $\begin{array}{l}0.509 * \\
(0.283)\end{array}$ & $\begin{array}{c}0.765 \\
(0.574)\end{array}$ \\
\hline Social network out-degree & $\begin{array}{l}-0.550 \\
(0.395)\end{array}$ & $\begin{array}{l}-0.179 \\
(0.466)\end{array}$ & $\begin{array}{c}0.543 \\
(0.357)\end{array}$ & $\begin{array}{l}-0.043 \\
(0.340)\end{array}$ & $\begin{array}{c}0.046 \\
(0.220)\end{array}$ & $\begin{array}{c}0.160 \\
(0.436)\end{array}$ & $\begin{array}{c}0.342 \\
(0.906)\end{array}$ & $\begin{array}{l}-0.042 \\
(0.280)\end{array}$ & $\begin{array}{c}0.238 \\
(0.370)\end{array}$ & $\begin{array}{c}0.118 \\
(0.260)\end{array}$ \\
\hline Treatment x Social network out-degree & $\begin{array}{l}-1.617 \\
(1.227)\end{array}$ & $\begin{array}{c}0.913 \\
(1.768)\end{array}$ & $\begin{array}{l}-0.642 \\
(0.848)\end{array}$ & $\begin{array}{l}-1.908 \\
(1.678)\end{array}$ & $\begin{array}{l}-1.006 \\
(1.007)\end{array}$ & $\begin{array}{l}-3.703 \\
(2.412)\end{array}$ & $\begin{array}{l}-1.359 \\
(1.480)\end{array}$ & $\begin{array}{c}3.256 \\
(5.341)\end{array}$ & $\begin{array}{c}-2.312 * * \\
(1.094)\end{array}$ & $\begin{array}{l}-1.050 \\
(0.987)\end{array}$ \\
\hline Constant & $\begin{array}{c}0.549^{* * *} \\
(0.143)\end{array}$ & $\begin{array}{c}0.459^{* * *} \\
(0.127)\end{array}$ & $\begin{array}{c}0.203 \\
(0.174)\end{array}$ & $\begin{array}{c}0.439 * * * \\
(0.125)\end{array}$ & $\begin{array}{c}0.348^{* * *} \\
(0.133)\end{array}$ & $\begin{array}{l}0.310^{* *} \\
(0.134)\end{array}$ & $\begin{array}{c}0.432 * * * \\
(0.121)\end{array}$ & $\begin{array}{c}0.538^{* *} \\
(0.207)\end{array}$ & $\begin{array}{c}0.362 * * * \\
(0.115)\end{array}$ & $\begin{array}{l}0.309 * * \\
(0.148)\end{array}$ \\
\hline Observations & 2688 & 2688 & 2688 & 2688 & 2688 & 2688 & 2688 & 2688 & 2688 & 2688 \\
\hline Number of center fixed effects & 157 & 157 & 157 & 157 & 157 & 157 & 157 & 157 & 157 & 157 \\
\hline R-squared & 0.01 & 0.01 & 0.01 & 0.01 & 0.01 & 0.01 & 0.01 & 0.01 & 0.01 & 0.01 \\
\hline
\end{tabular}

Robis A Panel A reports the regressions on indegree over maximum number of links possible. This measure reports how prestigious is the member in relation to the group size from a degree perspective (the member has more prestige if he/she receives many links); Panel B reports the regressions on outdegree over maximum number of links possible. This measure reports how central is the member in relation to the group size f.rom a degree perspective (the member is more central if he/she sends manylinks). See below for the definition of social network indices

Social network variables are defined as below:

1 Family: Have known this person since either one was a child (grandparents, parents, siblings, spouses, children, grandchildren, and cousins).

2 Friends: Have known this person since either one was a child (non-family members/relative)

3 Bought products: Have bought products or services from this person

4 Visit once a week: Visit this person house for social purposes at least once a week.

5 Knowledge index: Aggregate of 1 through 4

6 Given loan: Have given this person a loan outside of Bulak.

7 Voluntarily helped: Have voluntarily helped this person repay loans in Bulak.

8 Go for advise: Turn to this person for advise or help for any type of life problem; health, financial, or emotional.

9 Trust: Aggregate of 6 through 8

\# All: Aggregate of 1through 4, and 6 through 8. 
Table 11: Impact on Center-level Social Network

OLS, Difference-in-Difference

\begin{tabular}{|c|c|c|c|c|c|c|c|c|c|c|}
\hline & \multicolumn{4}{|c|}{ Knowledge } & \multirow[b]{2}{*}{$\begin{array}{l}\text { Knowledge } \\
\text { index } \\
\text { (5) }\end{array}$} & \multicolumn{3}{|c|}{ Trust } & \multirow[b]{2}{*}{$\begin{array}{c}\text { Trust index } \\
\text { (9) }\end{array}$} & \multirow[b]{2}{*}{$\begin{array}{c}\text { All } \\
(10)\end{array}$} \\
\hline & $\begin{array}{c}\text { Family } \\
\text { (1) }\end{array}$ & $\begin{array}{l}\text { Friends } \\
\text { (2) }\end{array}$ & $\begin{array}{l}\text { Buy products } \\
\text { (3) }\end{array}$ & $\begin{array}{c}\text { Visit once a } \\
\text { week } \\
\text { (4) }\end{array}$ & & $\begin{array}{c}\text { Given loan } \\
\text { (6) }\end{array}$ & $\begin{array}{c}\text { Voluntary } \\
\text { help } \\
(7)\end{array}$ & $\begin{array}{c}\text { Go for advice } \\
\text { (8) }\end{array}$ & & \\
\hline Treatment & $\begin{array}{l}-0.004 \\
(0.034)\end{array}$ & $\begin{array}{c}-0.001 \\
(0.010)\end{array}$ & $\begin{array}{c}-0.021 \\
(0.040)\end{array}$ & $\begin{array}{c}-0.003 \\
(0.030)\end{array}$ & $\begin{array}{c}-0.024 \\
(0.042)\end{array}$ & $\begin{array}{c}0.016 \\
(0.019)\end{array}$ & $\begin{array}{c}0.022 \\
(0.015)\end{array}$ & $\begin{array}{c}0.010 \\
(0.029)\end{array}$ & $\begin{array}{c}0.004 \\
(0.030)\end{array}$ & $\begin{array}{l}-0.020 \\
(0.040)\end{array}$ \\
\hline Post & $\begin{array}{l}-0.013 \\
(0.030)\end{array}$ & $\begin{array}{c}0.054^{* * *} \\
(0.009)\end{array}$ & $\begin{array}{c}0.000 \\
(0.035)\end{array}$ & $\begin{array}{c}0.102^{* * *} \\
(0.027)\end{array}$ & $\begin{array}{l}-0.046 \\
(0.037)\end{array}$ & $\begin{array}{c}0.051^{* * *} \\
(0.017)\end{array}$ & $\begin{array}{c}0.003 \\
(0.013)\end{array}$ & $\begin{array}{c}0.070^{* * *} \\
(0.026)\end{array}$ & $\begin{array}{c}0.072 * * * \\
(0.026)\end{array}$ & $\begin{array}{c}0.057 \\
(0.035)\end{array}$ \\
\hline Treatment x Post & $\begin{array}{l}-0.034 \\
(0.043)\end{array}$ & $\begin{array}{c}0.001 \\
(0.013)\end{array}$ & $\begin{array}{c}0.032 \\
(0.052)\end{array}$ & $\begin{array}{l}-0.039 \\
(0.039)\end{array}$ & $\begin{array}{c}0.024 \\
(0.054)\end{array}$ & $\begin{array}{c}-0.044^{*} \\
(0.025)\end{array}$ & $\begin{array}{l}-0.018 \\
(0.020)\end{array}$ & $\begin{array}{l}-0.033 \\
(0.038)\end{array}$ & $\begin{array}{l}-0.029 \\
(0.038)\end{array}$ & $\begin{array}{c}0.022 \\
(0.051)\end{array}$ \\
\hline Constant & $\begin{array}{c}0.258^{* * *} \\
(0.056)\end{array}$ & $\begin{array}{c}0.041^{* *} \\
(0.017)\end{array}$ & $\begin{array}{c}0.328 * * * \\
(0.067)\end{array}$ & $\begin{array}{c}0.058 \\
(0.051)\end{array}$ & $\begin{array}{c}0.512 * * * \\
(0.070)\end{array}$ & $\begin{array}{l}-0.001 \\
(0.032)\end{array}$ & $\begin{array}{c}0.012 \\
(0.026)\end{array}$ & $\begin{array}{c}0.033 \\
(0.049)\end{array}$ & $\begin{array}{c}0.052 \\
(0.050)\end{array}$ & $\begin{array}{r}0.442^{* * * *} \\
(0.067)\end{array}$ \\
\hline Observations & 273 & 273 & 273 & 273 & 273 & 273 & 273 & 273 & 273 & 273 \\
\hline R-squared & 0.09 & 0.35 & 0.24 & 0.28 & 0.26 & 0.17 & 0.07 & 0.22 & 0.22 & 0.29 \\
\hline
\end{tabular}

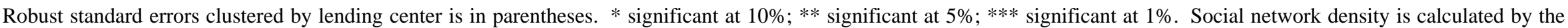

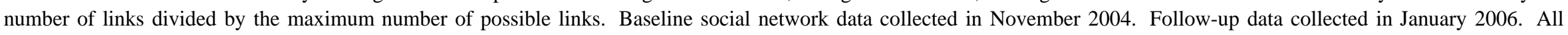
regressions use fixed effect for credit officers.

Social network variables are defined as below:

1 Family: Have known this person since either one was a child (grandparents, parents, siblings, spouses, children, grandchildren, and cousins).

2 Friends: Have known this person since either one was a child (non-family members/relative)

3 Bought products: Have bought products or services from this person

4 Visit once a week: Visit this person house for social purposes at least once a week.

5 Knowledge index: Aggregate of 1 through 4

6 Given loan: Have given this person a loan outside of Bulak.

7 Voluntarily helped: Have voluntarily helped this person repay loans in Bulak.

8 Go for advise: Turn to this person for advise or help for any type of life problem; health, financial, or emotional.

9 Trust: Aggregate of 6 through 8

10 All: Aggregate of 1 through 4, and 6 through 8. 


\section{Appendix Table 1: Reasons for Dropout}

Sample Frame Restricted to clients who dropped out from the program within three months of follow-up survey.

\begin{tabular}{|c|c|c|}
\hline & $\begin{array}{l}\text { Forced Out } \\
\text { Probit } \\
(1) \\
\end{array}$ & $\begin{array}{c}\text { Forced Out by Center or } \\
\text { Credit Officer } \\
\text { Multinomial Logit } \\
(2)\end{array}$ \\
\hline \multicolumn{3}{|c|}{ Dependent Variable: Forced Out } \\
\hline Treatment & $\begin{array}{c}-0.091^{* * *} \\
(0.012)\end{array}$ & \\
\hline \multicolumn{3}{|c|}{ Dependent Variable: Forced Out by Center Members } \\
\hline Treatment & & $\begin{array}{c}-0.539 * * * \\
(0.056)\end{array}$ \\
\hline \multicolumn{3}{|c|}{ Dependent Variable: Forced Out by Credit Officer } \\
\hline Treatment & & $\begin{array}{c}0.599 * * * \\
(0.102)\end{array}$ \\
\hline Observations & 520 & 520 \\
\hline R-squared & 0.007 & 0.017 \\
\hline
\end{tabular}

Robust standard errors clustered by respondents in parentheses, * significant at $10 \%$; ** significant at 5\%; *** significant at $1 \%$. Marginal coefficients reported for the probit specifications. The omitted variable for the multinomial-logit model in column (2) is voluntary dropout. "Forced out" and "Forced out by center members" include those clients who "voluntarily" dropped out because she was embarrassed for her bad performance. Dependent variable in column 1 is a categorical variable which equals to one if any respondent reported that the client was forced out by center members or by credit officers, and zero otherwise. Dependent variable in column 2 is a categorical variable which equals to one if any respondent reported that the client was forced out by center members, equals to two if anyone reported that the client was forced out by credit officer, and zero otherwise. 